Annals of Warsaw University of Life Sciences - SGGW

Land Reclamation No 49 (3), 2017: 143-152

(Ann. Warsaw Univ. of Life Sci. - SGGW, Land Reclam. 49 (3), 2017)

\title{
Assessment of sorption properties and kinetic reaction of phosphorus reactive material to limit diffuse pollution
}

\author{
AGNIESZKA BUS
}

Faculty of Civil and Environmental Engineering, Warsaw University of Life Sciences - SGGW

\begin{abstract}
Assessment of sorption properties and kinetic reaction of phosphorus reactive material to limit diffuse pollution. Polonite ${ }^{\circledR}$ is an effective reactive material (manufactured from opoka rock) for removing phosphorus from aqueous solutions. In conducted experiments, Polonite ${ }^{\circledR}$ of grain size of $2-5 \mathrm{~mm}$ was used as a potential reactive material which can be used as a filter fulfillment to reduce phosphorus diffuse pollution from agriculture areas. Kinetic and equilibrium studies (performed as a batch experiment) were carried out as a function of time to evaluate the sorption properties of the material. The obtained results show that Polonite ${ }^{\circledR}$ effectively removes such contamination. All tested concentrations $(0.998,5.213$, $10.965 \mathrm{mg} \mathrm{P}-\mathrm{PO}_{4} \cdot \mathrm{L}^{-1}$ ) are characterized by a better fit to pseudo-second kinetic order. The Langmuir isotherm the best reflects the mechanism of adsorption process in case of Polonite ${ }^{\circledR}$ and based on the isotherm, calculated maximum adsorption capacity equals $96.58 \mathrm{mg} \mathrm{P}-\mathrm{PO}_{4} \cdot \mathrm{g}^{-1}$.
\end{abstract}

Key words: phosphorous sorption, Polonite ${ }^{\circledR}$, diffuse pollution, reactive materials

\section{INTRODUCTION}

The excessive inflow of biogens loads coming from the agriculture land use to the water bodies is one of the most important environmental issues to be resolved worldwide (Yang et al. 2008). Phosphorus $(\mathrm{P})$ is one of macronutrients necessary for plants, and is used in the form of natural and mineral fertilizers to increase crop production. On the other hand, when too high dosage of the fertilizers do not fulfill requirements and needs of the plants during the vegetation period, losses of $\mathrm{P}$ to the environment are unavoidable. The unused by plants surplus of $\mathrm{P}$ are washed down from croplands as a result of surface runoff and infiltration, enter to drainage ditches, small streams, rivers and, in case of Poland, finally to the Baltic Sea. Phosphorus pollution of surface water contributes to deterioration of water quality, numerous limitations of water usage and eutrophication process.

The agriculture land use areas cover $59.6 \%$ of total area of Poland (GUS 2016a) and formation of diffuse pollution are associated with such land use. The sources of non-point pollution are mainly individually minor and inconsiderable, however collectively they may result in major environmental problems and damages. According to the HELCOM (2011) data, $48 \%$ of total phosphorus (TP) enter to the Baltic Sea comes from diffuse sources. In case of Poland, this kind of contaminations concerns $32 \%$ what responds to load of $2,200 \mathrm{Mg}$. year ${ }^{-1}$ (Frątczak et al. 2015). To the 2021 Poland pledged to reduce the TP load to the 3,890 Mg year ${ }^{-1}$ (HELCOM 2015). Despite of constant reduction of P load, from $12,100 \mathrm{Mg} \cdot \mathrm{year}^{-1}$ in 2000 to 4,800 $\mathrm{Mg} \cdot \mathrm{year}^{-1}$ in 2015 (GUS 2016b), it is still necessary to carry out appropriate techniques to further limit the P outflow. 
One of the method to limit P outflow from agriculture areas are filters filled with reactive material (RM) dedicated to remove P. Phosphorus reactive filters (PRFs) are different shape structures filled by RM and located at potential place of $\mathrm{P}$ occurrence (ditches, agriculture ponds, hot-spots etc.). The pilot scale implementations of PRFs with percentage removal of $\mathrm{P}$ are presented in Table 1.
Karczmarczyk 2017) or in geochemical barrier supporting buffer zones (Izydorczyk et al. 2013).

The most challenging in designing a PRF is a variable flow of water throughout the year that influence on contact time of RM with treatment water. This factor is a major challenge in using filter media for the adsorption of $\mathrm{P}$ contained surface water. For this reason, Ekstrand

TABLE 1. Pilot scale implementation of RM

\begin{tabular}{|l|l|c|l|}
\hline Type of system & \multicolumn{1}{|c|}{ Reactive material } & Efficiency (\%) & \multicolumn{1}{c|}{ Reference } \\
\hline Trench filter system & steel slag & $22.8-29.6$ & Wang et al. 2014 \\
\hline Phosphorus removal structure & $\begin{array}{l}\text { electric arc furnace } \\
\text { steel slag }\end{array}$ & 25.2 & Penn et al. 2012 \\
\hline Phosphorus socks & steel slag mixture & 44 & McDowell et al. 2007 \\
\hline Biogeochemical barrier & limestone & 58 & Izydorczyk et al. 2013 \\
\hline Filters & lime & $61.1-82.0$ & Kirkkala et al. 2012 \\
\hline Dispensers & ferric sulfate & $60-70$ & Uusitalo et al. 2015 \\
\hline Filter & crushed concrete & 90 & Sønderup et al. 2015 \\
\hline Filter wells & $\begin{array}{l}\text { Hyttsand, Polonite } \\
\text { Filtraline P }\end{array}$ & $19-49$ & Ulén et al. 2013 \\
\hline
\end{tabular}

Reactive material for $\mathrm{P}$ removal should contains in its composition $\mathrm{Ca}$, $\mathrm{Al}$ or $\mathrm{Fe}$ that have a high affinity for $\mathrm{P}$ (Cucarella et al. 2007, Cucarella et al. 2012). Such materials may be used in a different form: box systems filled with RM (Penn et al. 2012, Uusitalo et al. 2015), barriers located at potential ways of surface runoff (Kirkkala et al. 2012, Izydorczyk et al. 2013) or hanging and submerged directly into treatment water (McDowell et al. 2007, Karczmarczyk et al. 2016). Reactive materials may also support P removal efficiency at constructed wetland systems (Bus and et al. (2011) claim that contact time should be minimum $30 \mathrm{~min}$. The filter construction should provide: distributing the water entering the filter through the filter bed evenly, the particle size of used RM should not be caused filter clogging (> 1.0-2.0 $\mathrm{mm}$ ) and slow flow through the filter to achieve a sufficiently long contact time (Ulén et al. 2013).

The aim of the study is to assess sorption properties of phosphorus reactive material, Polonite ${ }^{\circledR}$ during kinetic and equilibrium tests, which may be potentially used for filter application to limit $\mathrm{P}$ contamination from diffuse pollution. 


\section{MATERIAL AND METHODS}

\section{Reactive material}

Polonite ${ }^{\circledR}$, used in this study, is factored from opoka which belongs to the group of silica-calcite sedimentary rocks. The main components of Polonite ${ }^{\circledR}$ is calcium and silicate however, their proportions may differ. In this study, the material of 2-5 mm grain size was used (Table 2). The material was mined in 2011 from Bełżec quarry.

The chemical and mineral composition of Polonite ${ }^{\circledR}$ was indicated by XRF (spectrometer PW 2400, Philips) and XRD (X-ray diffractometer PW 3020, Philips). Determination of bulk density and porosity was carried out in accordance with standards: PN-EN 1097-3:2000 and PN-EN 1936:2001. Hydraulic conductivity was determined by Witt apparatus.

\section{Kinetics and sorption equilibrium studies}

The kinetic and equilibrium tests were performed with triplicate samples of $1 \mathrm{~g}$ of material mixed in glass flask with 100 $\mathrm{mL}$ of artificial $\mathrm{P}$ solution prepared of $\mathrm{KH}_{2} \mathrm{PO}_{4}$. Thekinetictests were performed for three different initial $\mathrm{P}$ concentrations $\left(0.998,5.213,10.965 \mathrm{mg} \mathrm{P}_{-} \mathrm{PO}_{4} \cdot \mathrm{L}^{-1}\right)$ at various contact times (5-6,900 $\mathrm{min})$. The sorption equilibrium tests were performed at various $\mathrm{P}$ solution concentrations $\left(1.090-946.250 \mathrm{mg} \quad \mathrm{P}-\mathrm{PO}_{4} \cdot \mathrm{L}^{-1}\right)$ and constant time $(1 \mathrm{~h})$. The phosphorus equilibrium concentrations were measured by flow injection analyses using FIAstar 5000 (Foss).

Data on P-removal and equilibrium P-concentration obtained from experi-

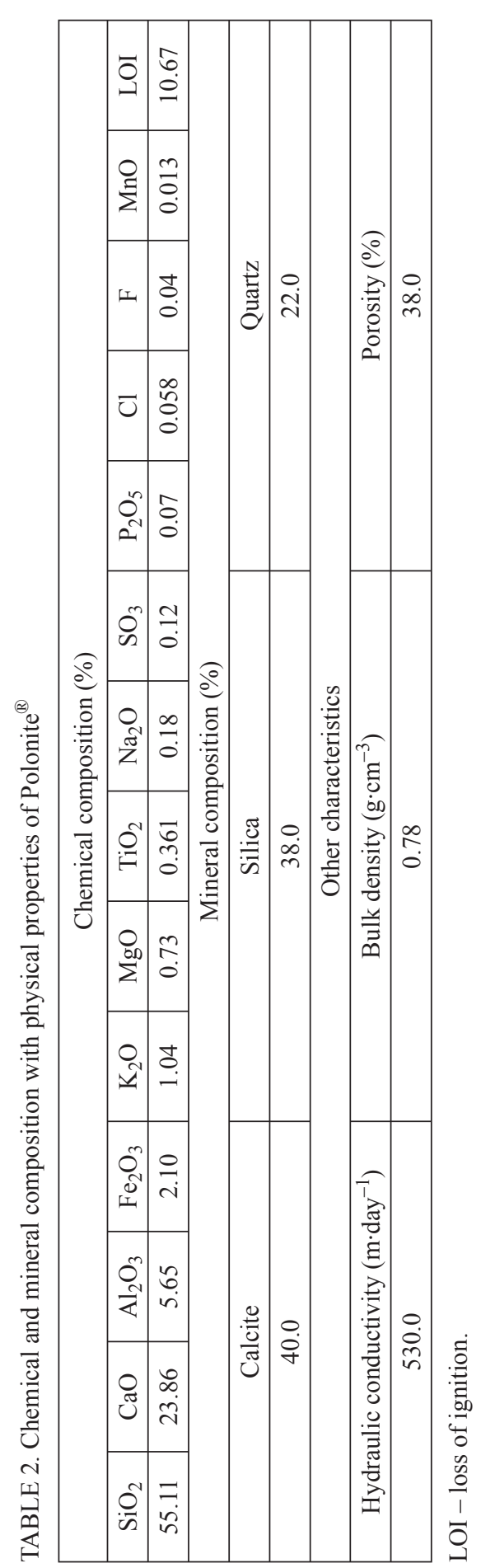


ments were fitted to the pseudo-first and pseudo-second kinetic order, Langmuir and Freundlich isotherm models.

A linear form of pseudo-first kinetic order described by Lagergren is (Ho 2006):

$\log \left(q_{e}-q\right)=\log \left(q_{e}\right)-\frac{K_{1} t}{2.303}$

where:

$q_{e}, q-$ adsorption capacities at equilibrium $\left(\mathrm{mg}^{-\mathrm{g}^{-1}}\right)$;

$K_{1}$ - rate constant of the first order adsorption $\left(\mathrm{min}^{-1}\right)$;

$\mathrm{t}$ - time (min).

A linear form of the pseudo-second kinetic order rate equation is (Ho 2006):

$\frac{t}{q}=\frac{1}{K_{2} q_{e}^{2}}+\frac{1}{q_{e}} t$

where:

$q$ - amount of ions on the surface of the adsorbent at any time $\left(\mathrm{mg} \cdot \mathrm{g}^{-1}\right)$;

$K_{2}$ - rate constant of adsorption $\left(\mathrm{g} \cdot \mathrm{mg}^{-1} \cdot \mathrm{min}^{-1}\right)$;

$q_{e}$ - amount of ions adsorbed at equilibrium $\left(\mathrm{mg}^{\circ} \mathrm{g}^{-1}\right)$.

Description of the sorption process between solid phase and solution was made based on mathematical equations given by Langmuir (McKay 1996):

$1 / q_{s}=1 / C_{S} \cdot 1 / K_{L}+a_{L} / K_{L}$

where:

$q_{s}$ - sorption;

$C_{S}$ - solute concentration at equilibrium;

$K_{L}$ - constant parameter reflects the solute adsorptivity;

$a_{L}-$ constant parameter related to the energy of adsorption;
$K_{L} / a_{L}$ - adsorption capacity.

and Freundlich equation (McKay 1996):

$\log q_{S}=b_{F} \cdot \log C_{S}+\log a_{F}$

where:

$q_{s}$ - sorption;

$b_{F}-$ heterogeneity factor;

$C_{\mathrm{s}}$ - solute concentration at equilibrium;

$a_{F}-$ constant which express the adsorbent capacity (the larger value, the higher the capacity).

The Langmuir isotherm describes adsorption on homogenous surfaces while the Freundlich one assumes surface which is heterogeneous.

The essential features of the Langmuir isotherm may be expressed in terms of equilibrium parameter $R L$, which is dimensionless constant referred to as separation factor or equilibrium parameter (Syed Shabudeen et al. 2006):

$R_{L}=\frac{1}{1+K_{L \cdot C_{0}}}$

where:

$K_{L}-$ constant related to the energy of adsorption (the Langmuir constant); $C_{0}$ - initial concentration.

The values of $R_{L}$ indicates the isotherm and adsorption nature to be either unfavorable if $R_{L}>1$, linear if $R_{L}=1$, favorable if $0<R_{L}<1$ or irreversible if $R_{L}=0$ (Syed Shabudeen et al. 2006).

\section{RESULTS AND DISCUSSION}

Simultaneous decreasing of $\mathrm{P}$ reduction with initial $\mathrm{P}$ concentration were observed (Fig. 1). After 6,900 min of contact time the final reduction is $94.7,92.0$ and $84.3 \%$ for initial concentration of 


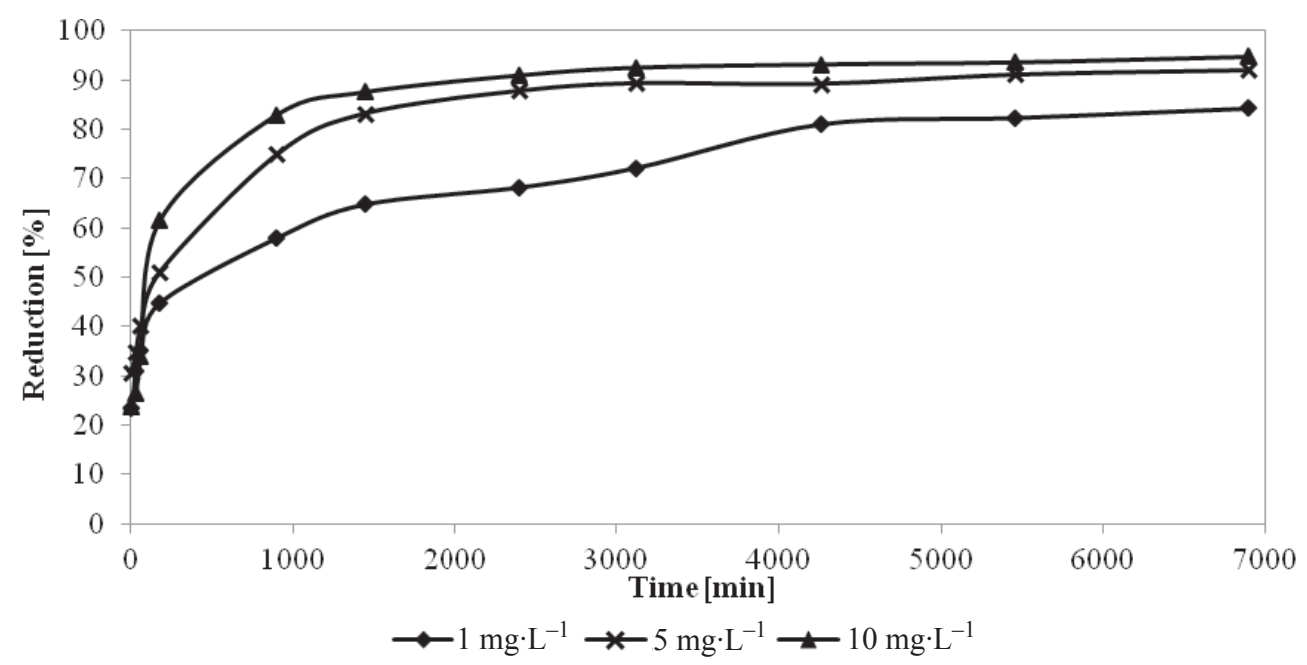

FIGURE 1. Phosphorus reduction in time for different initial concentrations

10.965, 5.213 and $0.998 \mathrm{mg} \mathrm{P-PO} \cdot \mathrm{L}^{-1}$, respectively. In case of 10.965 and $5.213 \mathrm{mg} \mathrm{P}-\mathrm{PO}_{4} \cdot \mathrm{L}^{-1}$ the equilibrium of $P$ removal was observed after 2,400 min. In case of concentration of $0.998 \mathrm{mg}$ $\mathrm{P}-\mathrm{PO}_{4} \cdot \mathrm{L}^{-1}$ the equilibrium was observed after 4,260 min. Further prolonged contact time of RM with $\mathrm{P}$ solution has not given a significant growth of $P$ reduction.

The experimental kinetic data for $\mathrm{P}$ adsorption onto Polonite ${ }^{\circledR}$ were fitted to the pseudo-first and pseudo-second kinetic models. Tested RM better fit to pseudo-second kinetic order in case of every tested initial concentration $\left(R^{2}>\right.$ $>99 \%$ )-Table 2 . The calculated $R^{2}$ values increase with increasing initial $P$ concen- tration $\left(C_{0}\right)$. The same observation was reported by Özacar (2003) and Eljamal et al. (2012). These indicate that pseudo-second kinetic order fit the best for the adsorption process of P onto Polonite ${ }^{\circledR}$.

A similar adsorption process have been observed for $\mathrm{P}$ with other natural materials such as sawdust, soil and rice husk (Eljamal et al. 2013), calcined alunite (Özacar 2003), marble dust (Eljamal et al. 2012) and palm fibers (Riahi et al. 2017).

Observed sorption of $\mathrm{P}$ characterized by good fit $\left(R^{2}=95.52 \%\right)$ to the initial $\mathrm{P}$ concentration $C_{i n}$ and the maximum observed sorption capacity equals $10.125 \mathrm{mg}$ P-PO $4 \cdot \mathrm{g}^{-1}$ (Fig. 2).

TABLE 2. Calculated parameter of pseudo-first and pseudo-second kinetic order

\begin{tabular}{|l|c|c|c|c|c|c|c|}
\hline \multirow{2}{*}{$\begin{array}{l}C_{0} \\
\left(\mathrm{mg} \cdot \mathrm{L}^{-1}\right)\end{array}$} & $\begin{array}{c}q_{e} \\
\text { experimental } \\
\left(\mathrm{mg} \cdot \mathrm{g}^{-1}\right)\end{array}$ & \multicolumn{2}{|c|}{ Pseudo-first order model } & \multicolumn{3}{|c|}{ Pseudo-second order model } \\
\cline { 3 - 8 } & $\mathrm{K}_{1}$ & $\begin{array}{c}q_{e} \\
\left(\mathrm{mg} \cdot \mathrm{g}^{-1}\right)\end{array}$ & $R^{2}$ & $\begin{array}{c}K_{2} \\
\left(\mathrm{~g} \cdot \mathrm{mg}^{-1} \cdot \mathrm{min}^{-1}\right)\end{array}$ & $\begin{array}{c}q_{e} \\
\left(\mathrm{mg} \cdot \mathrm{g}^{-1}\right)\end{array}$ & $R^{2}$ \\
\hline 0.998 & 0.084 & 0.001381 & 0.05205 & 97.52 & 0.048054 & 0.08463 & 99.21 \\
\hline 5.213 & 0.474 & 0.002072 & 0.21321 & 94.39 & 0.022763 & 0.47862 & 99.97 \\
\hline 10.965 & 1.033 & 0.002072 & 0.41594 & 88.02 & 0.011690 & 1.04416 & 99.99 \\
\hline
\end{tabular}




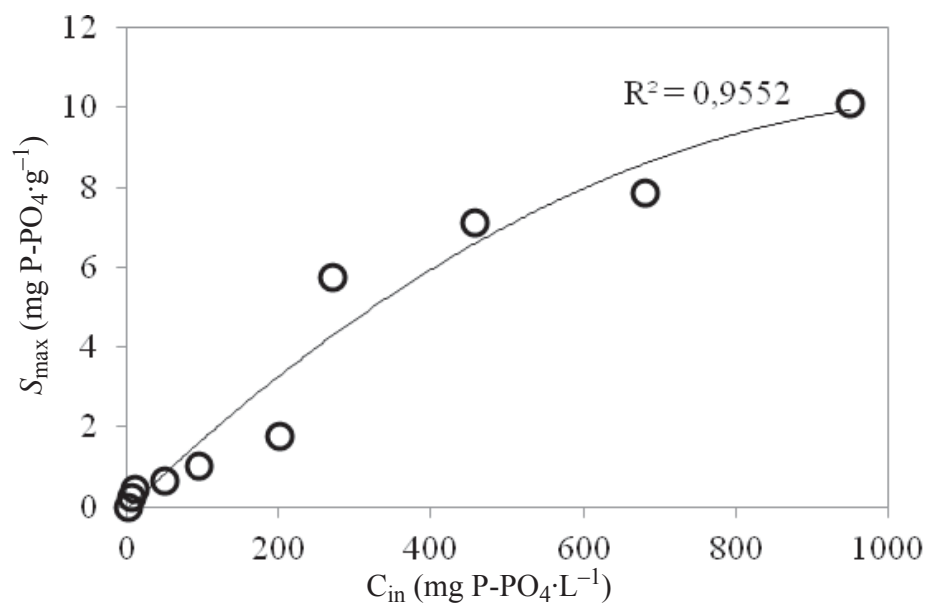

FIGURE 2. Phosphorus sorption on Polonite ${ }^{\circledR}$

The obtained results were analyzed assuming that the adsorption processes followed the Langmuir and Freundlich isotherm adsorption models. The data show a good compliance with the Langmuir isotherm equation and the regression coefficients for the linear plot were higher than for the Freundlich isotherm (Table 3). Maximal sorption capacity $\left(S_{\max }\right)$ calculated according the Langmuir isotherm parameters equals $96.58 \mathrm{mg} \mathrm{P}-\mathrm{PO}_{4} \cdot \mathrm{g}^{-1}$ is more than nine times higher than observed sorption during sorption test $\left(10.125 \mathrm{mg} \mathrm{P}-\mathrm{PO}_{4} \cdot \mathrm{g}^{-1}\right)$.

Because the Langmuir isotherm best reflects the mechanism of $\mathrm{P}$ sorption also the $R_{L}$ factor obtained from this isotherm indicate that adsorption model is favorable and $R_{L}$ equals 0.021 .

The equilibrium studies have been previously conducted with opoka as a phosphorous RM by Brogowski and Renman (2004), Cucarella et al. (2007) and Karczmarczyk and Bus (2014).

Cucarella et al. (2007) tested three kind of thermally treatment opoka coming from Strzeżów, Cisie and Widnica quarries. They obtained maximal sorption capacity $\left(S_{\max }\right)$ ranged from 79.37 to $181.82 \mathrm{mg} \mathrm{P}-\mathrm{PO}_{4} \cdot \mathrm{g}^{-1}$. The contact time during experiments was $1 \mathrm{~h}$. The differences of $S_{\max }$ values obtained by Cucarella et al. (2007) may be a result of way of conducting the batch test experiment. They used a powder fraction of material which is characterized by larger sorption area and better sorption efficiency (Cucarella and Renman 2009). On the other hand, the mass of used RM was quite low and the ratio of mass to volume was $0.2 \mathrm{~g}$ : $100 \mathrm{~mL}$.

TABLE 3. The Langmuir and Freundlich isotherm parameters for P adsorption

\begin{tabular}{|c|c|c|c|c|c|}
\hline \multicolumn{3}{|c|}{ Langmuir isotherm } & \multicolumn{3}{c|}{ Freundlich isotherm } \\
\hline$K_{L}\left(\mathrm{~L} \cdot \mathrm{g}^{-1}\right)$ & $a_{L}\left(\mathrm{~L} \cdot \mathrm{mg}^{-1}\right)$ & $R^{2}(\%)$ & $a_{F}\left(\mathrm{~L} \cdot \mathrm{g}^{-1}\right)$ & $b_{F}(-)$ & $R^{2}(\%)$ \\
\hline 42.551 & 0.4406 & 98.42 & 0.8341 & 1.411 & 92.82 \\
\hline
\end{tabular}


Similar value of $S_{\max }$ received Brogowski and Renman (2004). They calculated the sorption capacity of $119.6 \mathrm{~g}$ $\mathrm{P}-\mathrm{PO}_{4} \cdot \mathrm{kg}^{-1}$. However, there is no clearly defined, what was the grain size of material used in the study. There is also lack of information about batch test: contact time of material with solution, solution concentrations and ratio between mass of reactive material to solution. The tested material also came from Bełżec quarry.

Karczmarczyk and Bus (2014) tested 17 different reactive materials, among which was Polonite ${ }^{\circledR}$. Calculated $S_{\max }$ value was very close to this obtained in the study and equals $94.32 \mathrm{mg} \mathrm{P}-\mathrm{PO}_{4} \cdot \mathrm{g}^{-1}$. To both tests the grain size of used material and mass to volume ratio were the same. The difference concerns the contact time of materials with solution. In case of previous study (Karczmarczyk and Bus 2014), it was very short and equals only $15 \mathrm{~min}$. However, the calculated $S_{\max }$ value is similar to this obtained in this study $\left(96.58 \mathrm{mg} \mathrm{P}-\mathrm{PO}_{4} \cdot \mathrm{g}^{-1}\right)$. In this case, the contact time do not influence on the sorption and that may indicate a reached equilibrium.

Based on this study and the previous one (Brogowski and Renman 2004, Cucarella et al. 2007, Karczmarczyk and Bus 2014) the maximum sorption capacity of Polonite ${ }^{\circledR}$ is ranged from 79.37 to $181.82 \mathrm{mg} \mathrm{P}-\mathrm{PO}_{4} \cdot \mathrm{g}^{-1}$.

From practical point of view, the more useful and applied are kinetic studies. It makes possible to determinate the most appropriate contact time in dependence of initial P concentration. For instance, after $30 \mathrm{~min}$ of contact time recommended by Ekstrand et al. (2011) noted $P$ reduction equal 30, 35 and $27 \%$, what corresponds to sorption of $0.030,0.168$ and $0.305 \mathrm{mg} \cdot \mathrm{g}^{-1}$ for concentrations $0.998,5.213$ and $10.965 \mathrm{mg} \mathrm{P}-\mathrm{PO}_{4} \cdot \mathrm{L}^{-1}$, respectively. On the other hand, kinetic study conducted with artificial $P$ solution does not represent the condition of real surface water. Organic matter, inorganic anions and heavy metals may disturb and decrease the sorption process efficiency (Bastin et al. 1999).

Maximum sorption capacity $\left(S_{\max }\right)$ provides the information of sorption capacity and is useful to evaluate and selection of RMs, e.g. the higher the $S_{\max }$ value, the more reactive the material is. However, the mechanism of $\mathrm{P}$ reduction ( $\mathrm{Ca}$ or $\mathrm{Fe} / \mathrm{Al}$ ) should also be taken into account, because for this reason the observed sorption during laboratory tests may be similar, but modeled $S_{\max }$ may differ significantly (Bus and Karczmarczyk 2015).

Diffuse pollutions are difficult to limit and reduction because of significant area of occurrence. Contemporary trends of surface water protection against diffuse pollution include solutions, such as: creating buffer zones (Vought et al. 1995), phosphorous wetland (Ulén et al. 2013), biogeochemical barriers (Izydorczyk et al. 2013), and different kind of removal structure and box filters (Kirkkala et al. 2012, Penn et al. 2012, Wang et al. 2014, Sønderup et al. 2015, Uusitalo et al. 2015). Another method focused on $P$ removal from agriculture areas are suspended reactive filters - SRFs (Karczmaczyk et al. 2016). That may be used as a configuration of curtains consisting of filter bags filled with RM, hanged and suspended in the water. Such systems can be implemented at e.g. drainage ditches that are receivers of nutrients outflowing from agriculture areas, directly at the 
place of contamination occurrence. Suspended reactive filters may also be a support method to remove $\mathrm{P}$ concentration at constructed wetland designed to limit pollution from agriculture areas (Ulén et al. 2013, Bus et al. 2017).

\section{CONCLUSIONS}

Based on the obtained results, Polonite ${ }^{\circledR}$ is a high efficiency reactive material in $\mathrm{P}$ removal from aquatic solution. Both prolonged the contact time and initial $\mathrm{P}$ concentration play crucial role in increasing removal efficiency. The equilibrium sorption were $0.467 \mathrm{mg} \cdot \mathrm{g}^{-1}$ for initial concentration of 0.998 (after 4,260 min), 0.454 and $1.010 \mathrm{mg} \mathrm{P}-\mathrm{PO}_{4} \cdot \mathrm{L}^{-1}$ for concentrations 5.213 and $10.965 \mathrm{mg}$ $\mathrm{P}-\mathrm{PO}_{4} \cdot \mathrm{L}^{-1}$ (after 2,400 $\mathrm{min}$ ), respectively. Tested material is characterized by good adjusting both to the Langmuir and Freundlich isotherm models. Maximum sorption capacity based on the Langmuir isotherm equals $96.58 \mathrm{mg} \mathrm{P}-\mathrm{PO}_{4} \cdot \mathrm{g}^{-1}$.

\section{REFERENCES}

BASTIN O., JANSSENS F., DUFEY J., PEETERS A. 1999: Phosphorus removal by a synthetic iron oxide-gypsum compound. Ecol. Eng. 12, 339-351.

BROGOWSKI Z., RENMAN G. 2004: Characterization of opoka as a basis for its use in wastewater treatment. Pol. J. Environ. Stud. 13, 15-20.

BUS A., KARCZMARCZYK A. 2015: Kinetic and sorption equilibrium studies on phosphorus removal from natural swimming ponds by selected reactive materials. Fres. Env. Bull. 24, 2736-2741.

BUS A., KARCZMARCZYK A. 2017: Supporting constructed wetlands in $\mathrm{P}$ removal efficiency from surface water. Wat. Sci. and Tech. 75 (11), 2554-2561. doi 10.2166/wst.2017.134.

CUCARELLA V., RENMAN G. 2009: Phosphorus Sorption Capacity of Filter Materials Used for On-Site Wastewater Treatment Determined in Batch Experiments - A Comparative Study. J. Environ. Qual. 38, 381-392.

CUCARELLA V., ZALESKI T., MAZUREK R., 2007: Phosphorus sorption capacity of different types of opoka. Ann. Warsaw Univ. of Life Sci. - SGGW, Land Reclam. 38, 11-18.

CUCARELLA V., RENMAN G., ZALESKI T., MAZUREK R. 2012: Recycling of calcium-silicate material after wastewater filtration to agriculture - Soil condition impact. Ecol. Chem. Eng. S 19 (3), 373-382.

EKSTRAND S., PERSSON T., BERGSTRÖM R. 2011: Dikesfilter och dikesdammar. IVL rapport B2001. Retrieved from http://www.ivl.se/download/ 18.50a499dd132037d524e80008040/ /1321440587360/B2001.pdf.

ELJAMAL O., OKAWAUCHI J., HIRAMATSU K. 2012: Removal of Phosphorus from Water Using Marble Dust as Sorbent Material. J. Environ. Prot. 3, 709-714.

ELJAMAL O., OKAWAUCHI J., HIRAMATSU K., HARADA M. 2013: Phosphorus sorption from aqueous solution using natural materials. Environ. Earth Sci. 68, 859-863.

FRĄTCZAK W., IZYDORCZYK K., ŁAPIŃSKA M., SZUWART M., ZALEWSKI M. 2015. Ecotones for reducing diffuse pollution - Lyman's report. ERCE PAS, RWMA in Warsaw.

GUS 2016a. Statistical Yearbook of Agriculture. Warszawa.

GUS 2016b. Statistical Yearbook. Environment. Warszawa.

HELCOM 2011. The Fifth Baltic Sea Pollution Load Compilation (PLC-5). Balt. Sea Environ. Proc. 128. 
HELCOM 2015. Updated Fifth Baltic Sea pollution load compilation (PLC-5.5). Balt. Sea Environ. Proc. 145.

HO Y-S. 2006: Review of second-order models for adsorption systems. J. Hazard. Mater. 136, 681-689.

IZYDORCZYK K., FRĄTCZAK W., DROBNIEWSKA A., CICHOWICZ E., MICHALSKA-HEJDUK D., GROSS R., ZALEWSKI M. 2013: A biogeochemical barrier to enhance a buffer zone for reducing diffuse phosphorus pollution - preliminary results. Ecohydrol. Hydrobiol. 13, 104-112.

KARCZMARCZYK A., BUS A. 2014: Testing of reactive materials for phosphorus removal from water and wastewater - comparative study. Ann. Warsaw Univ. of Life Sci. - SGGW, Land Reclam. 46 (1), 57-67.

KARCZMARCZYK A., BUS A., BARYŁA A. 2016: Filtration curtains for phosphorus harvesting from small water bodies. Ecol. Eng. 86, 69-74.

KIRKKALA T., VENTELÄ A-M., TARVAINEN M. 2012: Long-Term Field-Scale Experiment on Using Lime Filters in an Agricultural Catchment. J. Environ. Qual. 41, 410-419.

McDOWELL R.W., HAWKE M., McINTOSH J.J. 2007: Assessment of a technique to remove phosphorus from streamflow. New Zealand J. Agri. Res. 50, 503-510.

McKAY G. (Ed.) 1996: Use of Adsorbents for the Removal of Pollutants from wastewater. CRC Press, Boca Raton.

ÖZACAR M. 2003: Equilibrium and Kinetic Modelling of Adsorption of Phosphorus on Calcined Alunite. Adsorpt. 9, 125-132.

PENN C.J., MCGRATH J.M., ROUNDS E., FOX G., HEEREN D. 2012: Trapping phosphorus in runoff with a phosphorus removal structure. J. Environ. Qual. 41, 672-679.

PN-EN 1097-3:2000. Tests for mechanical and physical properties of aggregates.
Determination of loose bulk density and voids [in Polish].

PN-EN 1936:2001. Natural stone test methods. Determination of real density and apparent density and of total and open porosity [in Polish].

RIAHI K., CHAABANE S., THAYER B.B. 2017: A kinetic modeling study of phosphate adsorption onto Phoenix dactylifera $\mathrm{L}$. date palm fibers in batch mode. J. Saudi Chem. Soc. 21, 143-152.

SØNDERUP M.J., EGEMOSE S., BOCHDAM T., FLINDT M.R. 2015: Treatment efficiency of a wet detention pond combined with filters of crushed concrete and sand: a Danish full-scale study of stormwater. Environ. Monit. Assess. 187, 758, 1-18.

SYED SHABUDEEN P.S., VENCKATESH R., SELVAM K., KADIRVELU K., PATTABHI S. 2006: Study of the removal of basic dye from aqueous solution by using solid agricultural waste. Indian J. Environ. Prot. 26/9, 822-837.

ULÉN B., PIETRZAK S., TONDERSKI K. 2013: Samoocena gospodarstw w zakresie zarządzania składnikami nawozowymi i oceny warunków środowiskowych. Wyd. ITP, Raszyn.

UUSITALO R., NÄRVÄNEN A., KASEVA A., LAUNTO-TIUTTU A., HEIKKINEN J., JOKI-HEISKALA P., RASA K., SALO T. 2015: Conversion of dissolved phosphorus in runoff by ferric sulfate to a form less available to algae: Field performance and cost assessment. AMBIO 44, 286-296.

VOUGHT LB-M., PINAY G., FUGLSANG A., RUFFINONI C. 1995: Structure and Function of Buffer Strips from a Water Quality Perspective in Agriculture Landscape, Landsc. Urban Plan. 31, 323-331.

WANG Z., BELL G.E.,PENN CH. J., MOSS J.Q., AND PAYTON M.E. 2014: Phosphorus Reduction in Turfgrass Runoff Using a Steel Slag Trench Filter System. Crop Sci. 54, 1859-1867.

YANG, X., WU, X., HAO, H., HE Z. 2008: Mechanisms and assessment of water eutrophication. J. Zhejiang Univ. Sci. B 9, 197-209. 
Streszczenie: Ocena właściwości sorpcyjnych $i$ kinetyka reakcji materiatu reaktywnego do usuwania fosforu $z$ zanieczyszczeń obszarowych. Polonite ${ }^{\circledR}$ jest materiałem reaktywnym służącym do usuwania fosforu z roztworów wodnych. W przeprowadzonych badaniach Polonite ${ }^{\circledR}$ o frakcji 2-5 mm został użyty jako potencjalny materiał reaktywny służący do wypełnienia filtrów do redukcji fosforu pochodzącego $\mathrm{z}$ obszarowych źródeł zanieczyszczeń. Ocena zdolności sorpcyjnych materiału została przeprowadzona na podstawie krótkich testów kontaktowych typu batch. Otrzymane wyniki pokazują, że badany materiał skutecznie usuwa fosfor. Wyniki uzyskane podczas testów kinetyki mają lepsze dopasowanie do pseudo drugiego rzędu reakcji. W wynikach badań sorpcji równowagowej model izotermy Langmuira lepiej odzwierciedla mechanizm adsorpcji fosforu. Wyliczona na podstawie izotermy Langmuira, maksymalna zdolność sorpcyjna fosforu wynosi $96,58 \mathrm{mg} \mathrm{P}-\mathrm{PO}_{4} \cdot \mathrm{g}^{-1}$.

MS received July 2017

\section{Author's address:}

Agnieszka Bus

Katedra Kształtowania Środowiska

Wydział Budownictwa i Inżynierii Środowiska

SGGW

ul. Nowoursynowska 166

02-787 Warszawa

Poland

e-mail: agnieszka_bus@sggw.pl 